\title{
Article \\ Alcohol-Induced Blood-Brain Barrier Impairment: An In Vitro Study
}

\author{
Donatello Carrino ${ }^{1,+}{ }^{+}$Jacopo Junio Valerio Branca ${ }^{1,+}+\mathbb{C}$, Matteo Becatti ${ }^{2}{ }^{\oplus}$, Ferdinando Paternostro ${ }^{1}$, \\ Gabriele Morucci ${ }^{3}$, Massimo Gulisano ${ }^{1}$, Lorenzo Di Cesare Mannelli ${ }^{4}(\mathbb{D})$ and Alessandra Pacini ${ }^{1, *}$
}

1 Department Experimental and Clinical Medicine, Anatomy and Histology Section, University of Firenze, 50134 Firenze, Italy; donatello.carrino@unifi.it (D.C.); jacopojuniovalerio.branca@unifi.it (J.J.V.B.); ferdinando.paternostro@unifi.it (F.P.); massimo.gulisano@unifi.it (M.G.)

2 Department of Experimental and Clinical Biomedical Sciences "Mario Serio", University of Firenze, 50134 Firenze, Italy; matteo.becatti@unifi.it

3 Department of Translational Research and New Technologies in Medicine and Surgery, University of Pisa, 56126 Pisa, Italy; gabriele.morucci@unipi.it

4 Department of Neuroscience, Psychology, Drug Research and Child Health (NEUROFARBA), Pharmacology and Toxicology Section, University of Firenze, 50139 Firenze, Italy; lorenzo.mannelli@unifi.it

* Correspondence: alessandra.pacini@unifi.it

+ These Authors contributed equally to the work.

check for

updates

Citation: Carrino, D.; Branca, J.J.V.; Becatti, M.; Paternostro, F.; Morucci,

G.; Gulisano, M.; Di Cesare Mannelli,

L.; Pacini, A. Alcohol-Induced

Blood-Brain Barrier Impairment: An In Vitro Study. Int. J. Environ. Res. Public Health 2021, 18, 2683. https:// doi.org/10.3390/ijerph18052683

Academic Editor: Elisardo Becoña Iglesias

Received: 18 February 2021

Accepted: 4 March 2021

Published: 7 March 2021

Publisher's Note: MDPI stays neutral with regard to jurisdictional claims in published maps and institutional affiliations.

Copyright: (c) 2021 by the authors. Licensee MDPI, Basel, Switzerland. This article is an open access article distributed under the terms and conditions of the Creative Commons Attribution (CC BY) license (https:// creativecommons.org/licenses/by/ $4.0 /)$
Abstract: In recent years, alcohol abuse has dramatically grown with deleterious consequence for people's health and, in turn, for health care costs. It has been demonstrated, in humans and animals, that alcohol intoxication induces neuroinflammation and neurodegeneration thus leading to brain impairments. Furthermore, it has been shown that alcohol consumption is able to impair the bloodbrain barrier (BBB), but the molecular mechanisms underlining this detrimental effect have not been fully elucidated. For this reason, in this study we investigated the effects of alcohol exposure on a rat brain endothelial (RBE4) cell line, as an in vitro-validated model of brain microvascular endothelial cells. To assess whether alcohol caused a concentration-related response, the cells were treated at different times with increasing concentrations $(10-1713 \mathrm{mM})$ of ethyl alcohol $(\mathrm{EtOH})$. Microscopic and molecular techniques, such as cell viability assay, immunofluorescence and Western blotting, were used to examine the mechanisms involved in alcohol-induced brain endothelial cell alterations including tight junction distribution, apoptosis, and reactive oxygen species production. Our findings clearly demonstrate that alcohol causes the formation of gaps between cells by tight junction disassembly, triggered by the endoplasmic reticulum and oxidative stress, highlighted by GRP78 chaperone upregulation and increase in reactive oxygen species production, respectively. The results from this study shed light on the mechanisms underlying alcohol-induced blood-brain barrier dysfunction and a better understanding of these processes will allow us to take advantage of developing new therapeutic strategies in order to prevent the deleterious effects of alcohol.

Keywords: alcoholism; alcohol abuse; oxidative stress; blood-brain barrier; tight junction

\section{Introduction}

In the last couple of years, alcohol has been listed as one of the main dependent drugs worldwide. Data from the World Health Organization (WHO) indicate that more than 3 million people died as a result of harmful use of alcohol in 2016 [1], including it as one of the leading risk factors for population health worldwide.

Alcohol abuse not only impairs liver function (steatosis, hepatitis and cirrhosis) [2], but also can lead to cardiovascular diseases [3], malignant neoplasms [4], infectious diseases [5] and digestive disorders (such as pancreatitis) [6,7]. Moreover, since alcohol has been listed as a psychoactive substance, it induces mental disorders such as depression and psychoses. Indeed, alcohol intoxication has been observed to induce neuroinflammation and neurodegeneration in humans and animals [8-10]. Recently, many neurological 
disorders have been associated to alcohol abuse such as Parkinson's disease, epilepsy, and many others [11-14].

Neurodegenerative disorders are debilitating pathologies affecting both the central and peripheral nervous systems and represent a growing health issue worldwide [15]. However, the etiopathogenesis of such debilitating diseases needs to be clarified and deeply investigated. In the last decade, many hypotheses have come to light including the inflammatory hypotheses involving the glial compartment [16-18] and the blood-brain barrier (BBB) alterations [19-21].

The BBB plays a pivotal role in discerning harmful from harmless substances in the bloodstream entering the brain parenchyma [22]. It is characterized by the presence of different cellular components such as endothelial cells, pericytes and astrocyte end-feet that are all essential for the correct BBB function [23-25]. Notably, endothelial cells are sealed to each other by the presence of tight junctions' proteins, avoiding the entrance of toxic molecules that can alter the brain physiology [26,27]. Indeed, many studies have underlined the primary role of endothelial cells in maintaining the homeostasis of the central nervous system, whose impairment leads to neurodegeneration $[19,21,28-30]$.

Previous studies have clearly indicated that chronic and excessive ethanol $(\mathrm{EtOH})$ consumption may enhance oxidative injury of neural cells by increasing reactive oxygen species (ROS) production [31,32]. In addition, oxidative stress was demonstrated to increase BBB permeability after different toxic stimuli both in vitro and in vivo models [33,34]. Overall, little is known about the mechanisms involved in $\mathrm{BBB}$ alterations during excessive alcohol consumption.

Using a rat brain endothelial (RBE4) cell line, and our previously developed in vitro BBB model [35,36], we demonstrated that EtOH decreased Zonula Occludens 1 (ZO-1) tight junction (TJ) integrity via induction of endoplasmic reticulum (ER) stress and Bcl2 -associated $\mathrm{X}$ protein (BAX) expression. Additionally, the current study addresses the role of oxidative stress in ZO-1 alteration caused by Et-OH exposure. Finally, our data demonstrate a clear link amongst RBE4 alcohol metabolism, oxidative stress, and ZO-1 and cytoskeletal protein alterations.

\section{Materials and Methods}

\subsection{Cell Culture and Treatments}

Rat brain endothelial cell line (RBE4) cultures were maintained in $75 \mathrm{~cm}^{2}$ flasks (Euroclone, Milan, Italy) as previously described [35,36]. In brief, cells were cultured in alpha-MEM/Ham's F10 (1:1 ratio) supplemented with $1 \mathrm{ng} / \mathrm{mL}$ (bFGF) (GIBCO, Thermo Fisher Scientific, Milan, Italy), 10\% FBS, 1\% penicillin/streptomycin (Euroclone, Milan, Italy) at $37^{\circ} \mathrm{C}, 5 \% \mathrm{CO}_{2}$ in humidified atmosphere.

To assess whether alcohol caused a concentration-related response, cells were treated with increasing concentrations $(10,35,50,75,100,171.3$ or $1713 \mathrm{mM})$ of ethyl alcohol $(\mathrm{EtOH})$ at different times. These concentrations are equal or equivalent to two or three times the legal limits for blood alcohol concentration in Italy (corresponding to $0.5 \mathrm{~g} / \mathrm{L}$ as declared on the D. L. 30 aprile 1992, n. 285, art. 186) (http:/ / www.mit.gov.it/mit/site.php? $\mathrm{p}=$ normativa\&o=vd\&id=1\&id_cat=\&id_dett $=0$ (accessed on 7 March 2021)).

The EtOH withdrawal experiments were performed replacing the medium with EtOHfree medium for the following 24 and $48 \mathrm{~h}$.

\subsection{MTT Assay}

RBE4 cells were gently seeded at a density of $2.5 \times 10^{4}$ cells/well in 96-well plates in growth medium for $24 \mathrm{~h}$. The following day, the medium was replaced with starvation medium (without FBS and bFGF) and RBE4 cells were treated with different concentrations of EtOH for 30, 60, 120, 240 min. Cell viability was evaluated using the MTT (3-(4,5-dimethylthiozol-2-yl)-2,5-diphenyltetrazolium bromide) assay, based on the reduction of the tetrazolium salt to formazan by mitochondrial dehydrogenases. After the treatments, $1 \mathrm{mg} / \mathrm{mL}$ of MTT solution (Sigma Aldrich, Milan, Italy) was added into each well at 
the final volume of $100 \mu \mathrm{L}$. After $30 \mathrm{~min}$, formazan crystals were dissolved by adding $100 \mu \mathrm{L}$ of dimethyl sulfoxide (DMSO) (Sigma Aldrich, Milan, Italy) and optical density was measured at $570 \mathrm{~nm}$ using a microplate reader (MultiskanFC ${ }^{\mathrm{TM}}$ microplate photometer, ThermoFisher Scientific, Milan, Italy).

\subsection{Western Blotting}

Cells were gently seeded in $100 \mathrm{~mm} \varnothing$ Petri dishes (Euroclone, Milan, Italy) with the appropriate growth medium for $24 \mathrm{~h}$, at a density of $4 \times 10^{6}$ cells/dish. The following day, the culture medium was substituted with starvation medium and different concentrations of alcohol were added. After stimulation, cells were harvested and lysed by incubation for $30 \mathrm{~min}$ at $4{ }^{\circ} \mathrm{C}$ in RIPA buffer (Euroclone, Milan, Italy) and protease inhibitor cocktail (Sigma Aldrich, Milan, Italy) according to the manufacturer's instructions. Cellular debris were removed by centrifugation at 12,000 revolutions per minute $(\mathrm{rpm})$ for $10 \mathrm{~min}$ at $4{ }^{\circ} \mathrm{C}$. After determination of protein concentration in each sample by bicinchoninic acid (BCA) protein assay (Sigma Aldrich, Milan, Italy), $30 \mu \mathrm{g}$ of the total proteins was loaded on 4-12\% acrylamide/bis-acrylamide (Euroclone, Milan, Italy) gels, and then transferred to nitrocellulose membranes (Porablot NPC, MACHEREY-NAGEL, Milan, Italy). The blotted proteins were blocked with bovine serum albumin (BSA; CliniSciences, Guidonia Montecelio, Italy) at 3\% in tween-tris buffered saline (tTBS) solution for $30 \mathrm{~min}$ at room temperature (RT). After that, the nitrocellulose membranes were soaked with proper primary antibody as reported in Table 1 diluted in blocking solution, overnight at $4{ }^{\circ} \mathrm{C}$. The following day, appropriate HRP-conjugated secondary antibodies (Santa Cruz Biotechnology, Santa Cruz, CA, USA) were used at 1:5000 dilution for $1 \mathrm{~h}$ at RT. Protein bands were detected by ECL Plus Western Blotting Detection Reagent (GE Healthcare, Milan, Italy). Band density was determined using ImageJ software v. 1.52a (National Institute of Health, Bethesda, USA). $\beta$-actin or $\alpha$-tubulin were used as internal loading control to normalize the expression of proteins of interest.

Table 1. Primary antibody for Western blotting analysis.

\begin{tabular}{cccc}
\hline & Dilution & Manifacturer & Host \\
\hline GRP78 & $1: 500$ & ThermoFisher Sientific, Milan, Italy & rabbit \\
\hline ZO-1 & $1: 500$ & ThermoFisher Sientific, Milan, Italy & rabbit \\
\hline $\begin{array}{c}\text { SOD1 } \\
\text { SOD2 }\end{array}$ & $1: 5000$ & GeneTex, Prodotti Gianni, Milan, Italy & rabbit \\
\hline BAX & $1: 200$ & Santa Cruz Biotechnology, Santa Cruz, CA, USA & rabbit \\
\hline$\beta$-actin & $1: 10,000$ & Santa Cruz Biotechnology, Santa Cruz, CA, USA & mouse \\
\hline$\alpha$-tubulin & $1: 10,000$ & Santa Cruz Biotechnology, Santa Cruz, CA, USA & mouse \\
\hline
\end{tabular}

\subsection{Measurement of ROS}

RBE4 cells were gently seeded into a 96-well plate and allowed to adhere for $24 \mathrm{~h}$, at $2.5 \times 10^{4}$ cells/well. The following day, after removing growth medium, cells were loaded with $5 \mu \mathrm{M} \mathrm{CM}-\mathrm{H}_{2}$ DCFDA (Life Technologies, ThermoFisher Scientific, Milan, Italy) for $30 \mathrm{~min}$ at $37^{\circ} \mathrm{C}$ in $5 \% \mathrm{CO}_{2}$, protected from light. After washing with PBS, the cells were exposed to treatments: control (PBS only; $0 \mathrm{mM} \mathrm{EtOH}$ ), $50 \mathrm{mM} \mathrm{EtOH}, 75 \mathrm{mM}$ EtOH or $100 \mathrm{mM} \mathrm{EtOH}$. The fluorescence, resulting from the conversion of dichlorofluorescin diacetate (DCFH-DA) to dichlorofluorescein (DCF), was measured after 30, 120, $240 \mathrm{~min}$ using a VICTOR microplate reader (PerkinElmer, Milan, Italy) set to an excitation wavelength of $485 \mathrm{~nm}$ and an emission wavelength of $530 \mathrm{~nm}$. The amount of fluorescence was directly correlated to the amount of ROS within the cells. 


\subsection{Immunofluorescent Labelling}

RBE4 cells were gently seeded at a density of $5 \times 10^{4}$ on sterilized coverslips, lodged in 6-well plates, in complete growth medium for at least $24 \mathrm{~h}$. After growing to the required density, RBE4 were stimulated and then fixed with $4 \%$ formaldehyde for $10 \mathrm{~min}$ at RT or with cold methanol for $20 \mathrm{~min}$. Cells were permeabilized with $0.1 \%$ Triton X-100 (Sigma Aldrich, Milan, Italy) in PBS for 10 min, blocked with 1\% BSA in $0.1 \%$ Triton X-100 in PBS for 30 min and incubated with ZO-1 primary antibody (ThermoFisher Scientific, Milan, Italy) diluted in blocking solution (1:50), overnight at $4{ }^{\circ} \mathrm{C}$. The following day, the cover slips were washed three times in PBS and incubated with the appropriate AlexaFluor 488 secondary antibodies (Invitrogen, ThermoFisher Scientific, Milan, Italy) at 1:200 dilution in blocking solution for $1 \mathrm{~h}$ at RT. Cells were counterstained with DAPI (4',6-diamidin-2fenilindolo; 1:2000 dilution; Invitrogen, Milan, Italy) to visualize cellular nuclei. Samples were examined under a fluorescence microscope (Leica DM6000B microscope equipped with a DFC350FX camera) at the total magnification of $400 \times$.

\subsection{Statistical Analysis}

Each experimental data was expressed as mean \pm S.E.M. (standard error of the mean). For MTT assay, we performed experiments three times in quintuplicate.

For Western blotting analysis and ROS evaluation, each experiment was performed three times, in triplicate.

For immunofluorescence staining analysis, we performed three different experiments and fifteen images per experimental point were captured.

Statistical analysis was performed with one-way ANOVA followed by Dunnett post hoc test.

In each comparison, differences were considered significant when $p$ value was less than $0.05\left({ }^{*} p<0.05\right)$.

\section{Results}

\subsection{RBE4 Cell Viability}

In order to evaluate the EtOH effects on RBE4 cells viability, we performed the MTT assay with different concentrations of EtOH (ranging from 10 to $1713 \mathrm{mM}$ ) at different timepoints (from $30 \mathrm{~min}$ to $2 \mathrm{~h}$ ). As clearly shown in Figure 1, RBE4 cell viability decreased significantly $(* p<0.05)$ only at the highest EtOH concentration $(1713 \mathrm{mM})$. A slight but significant increase in cell viability at $1 \mathrm{~h}$ timepoint was evidenced that could be attributed to an increase in cellular metabolism because alcohol is an energy-yielding nutrient.

On the other hand, for EtOH concentrations ranging from 35 to $100 \mathrm{mM}$, cell viability was unchanged in respect to control levels. In addition, the EtOH concentrations and the time of exposure used in this study are similar to those seen in the peripheral blood of moderately to severely intoxicated humans $[37,38]$, and in vivo experimental models of chronic alcohol abuse $[39,40]$. For these reasons, these concentrations were used in all subsequent experiments. 


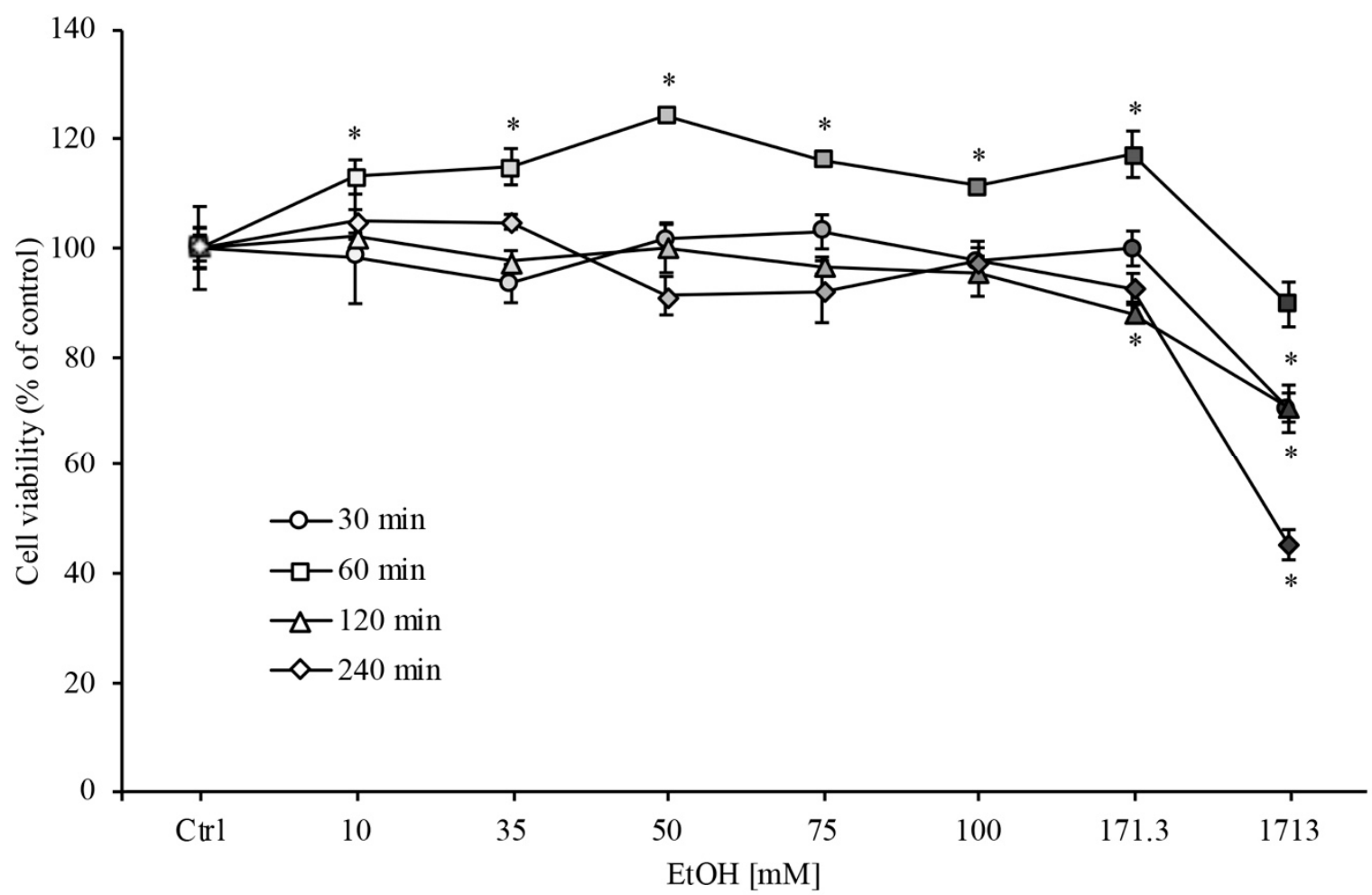

Figure 1. RBE4 cell viability assay during ethanol (EtOH) treatment. RBE4 cells were incubated with increasing EtOH concentrations (10-1731 mM) for $30 \mathrm{~min}, 1,2$ and $4 \mathrm{~h}$. Cell viability, quantified by MTT (3-(4,5-di-methylthiozol-2-yl)-2,5diphenyltetrazolium bromide) assay ( $570 \mathrm{~nm}$ wavelength absorbance), decreased significantly $\left.{ }^{*} p<0.05\right)$ only at the highest EtOH concentrations. Values are expressed in percentage of control (untreated cells) absorbance as the mean \pm S.E.M. of three independent experiments in quintuplicate. Grayscale refers to the increasing EtOH concentration. ${ }^{*} p<0.05$ vs. control (untreated cells).

\subsection{Evaluation of ROS Generation}

The intracellular ROS quantification in RBE4 cells was carried out by a chemiluminescent analysis. As reported in Figure 2, the EtOH intoxication induced a first ROS production peak at the highest concentration $(100 \mathrm{mM})$ at $30 \mathrm{~min}$ timepoint in comparison to control levels. Furthermore, a significant increase in ROS production after $4 \mathrm{~h}$ timepoint has been observed at all EtOH concentrations used.

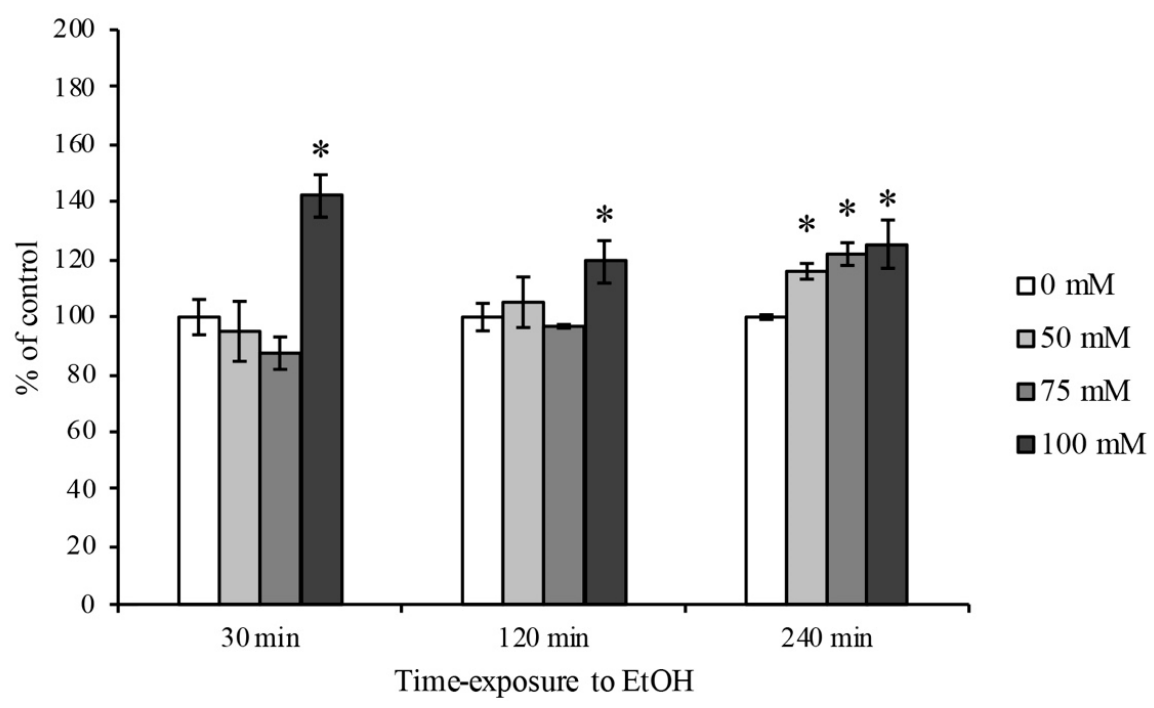

Figure 2. ROS quantification on RBE4 cells after EtOH treatment. Representative ROS production by 
$\mathrm{H}_{2}$ DCFDA fluorescence probe after $\mathrm{EtOH}(50,75$ and $100 \mathrm{mM})$ treatment at $30 \mathrm{~min}, 2$ and $4 \mathrm{~h}$ timepoints. The reported values are expressed in percentage of control (untreated cells) as the mean \pm S.E.M. of three independent experiments in triplicate. ${ }^{*} p<0.05$ vs. control for each timepoint.

\subsection{BAX Protein Expression Levels}

The protein expression of BAX was used in order to evaluate cell apoptosis after 2 and $4 \mathrm{~h}$ treatment with increasing concentrations of EtOH. In this regard, we focused on the balance between BAX dimers (37 kDa) and monomers $(23 \mathrm{kDa})$. As reported by Garner and colleagues, when BAX is present in dimeric form, BAX-mediated apoptosis induction is hindered, whereas the presence of monomeric BAX triggers the apoptotic cascade [41]. As shown in Figure 3, the ratio between the monomeric and dimeric form significantly increased after $2 \mathrm{~h}$ of treatment. On the contrary, after $4 \mathrm{~h}$ of EtOH treatment, BAX balance moved towards the dimeric form, showing a decrease in monomeric and dimeric ratio, suggesting for an autoinhibited apoptosis.

\section{BAX expression}
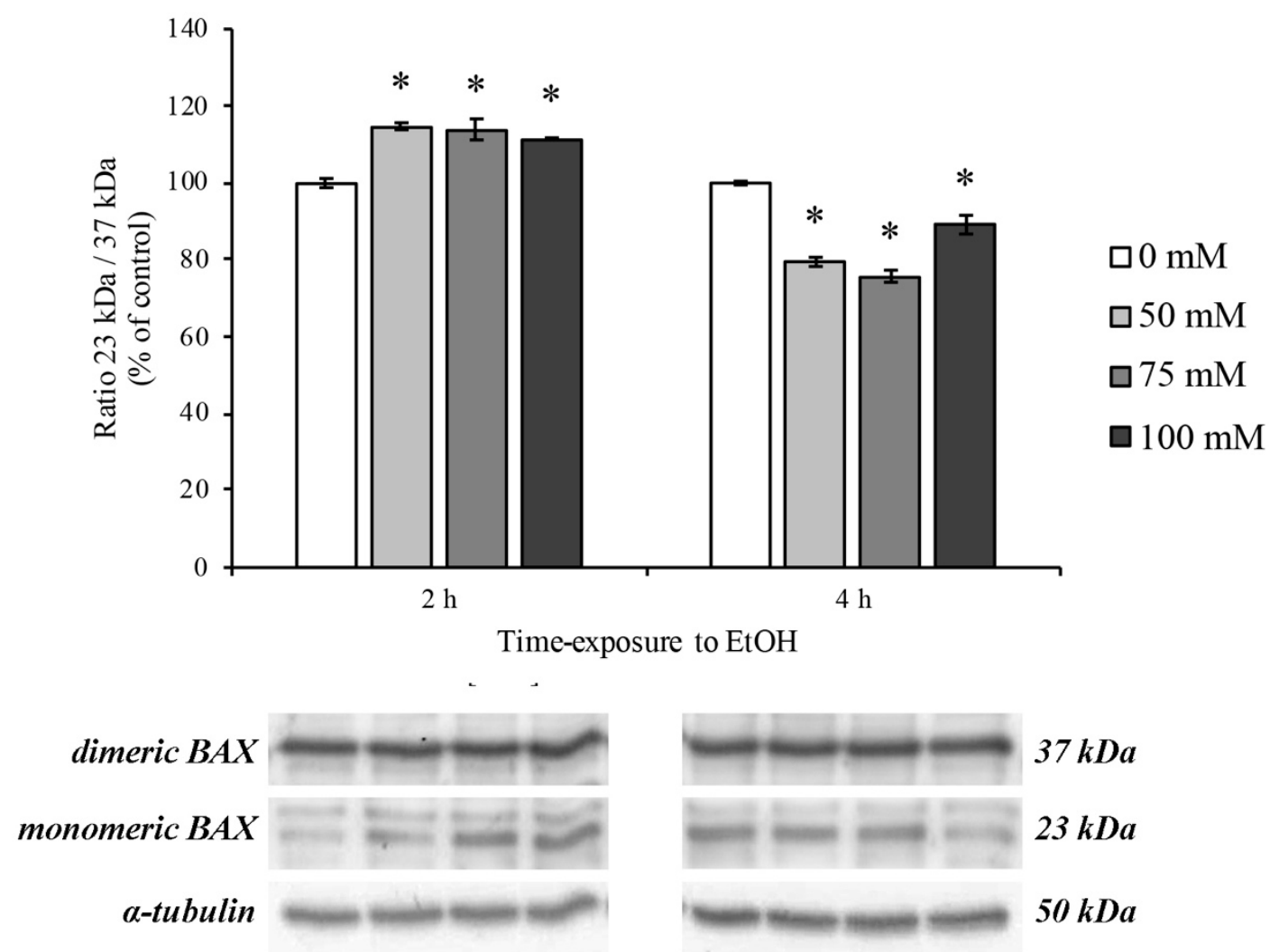

Figure 3. Bcl-2-associated protein (BAX) expression on RBE4 cells after EtOH treatment. Representative Western blotting analysis of the EtOH (50-100 mM) effects on the protein levels of dimeric (upper bars) and monomeric (lower bars) BAX after 2 and $4 \mathrm{~h}$ of treatment. Value bars are expressed in percentage of control (untreated cells) as the mean \pm S.E.M. of three independent experiments in triplicate. ${ }^{*} p<0.05$ vs. control.

These events were completely restored after EtOH withdrawal for the following 24 and $48 \mathrm{~h}$ (Figure 4). 
BAX expression after $4 \mathrm{~h}$ EtOH
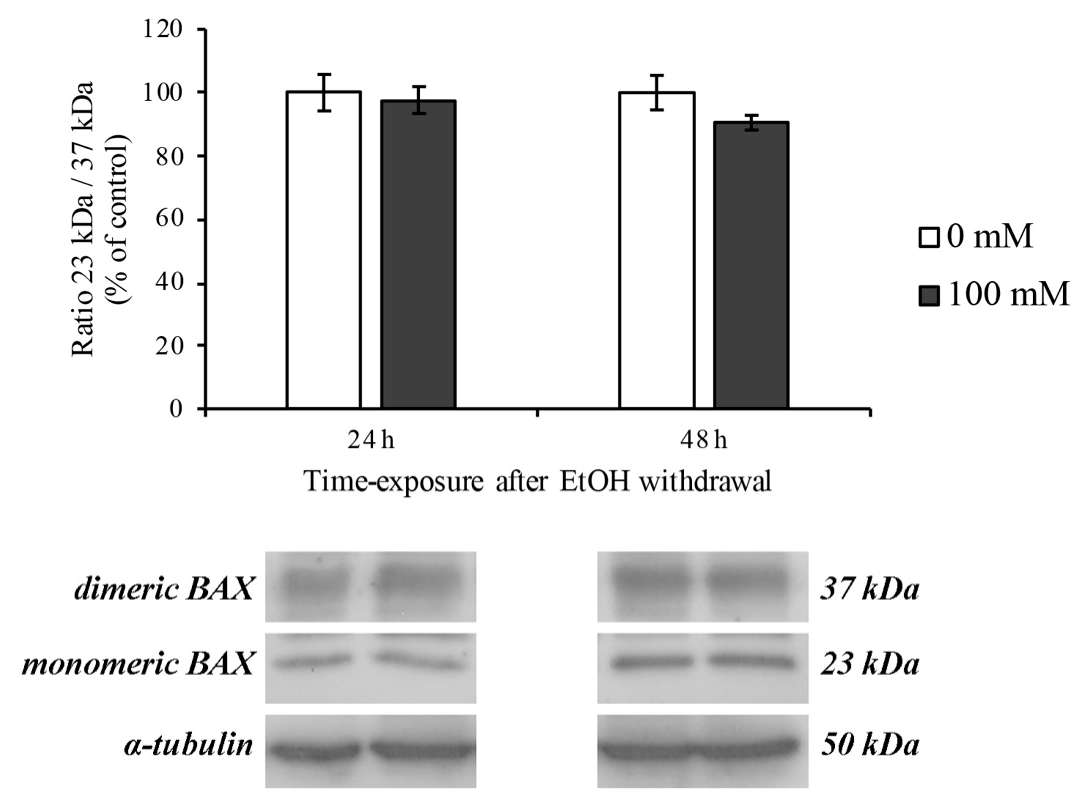

Figure 4. BAX expression on RBE4 cells after EtOH withdrawal. Representative Western blotting analysis after EtOH $100 \mathrm{mM}$ withdrawal for 24 and $48 \mathrm{~h}$. Value bars are expressed in percentage of control (untreated cells) as the mean \pm S.E.M. of three independent experiments in triplicate.

\subsection{EtOH-Dependent ER Stress}

Since a pivotal role in oxidative stress has been attributed both to mitochondrial and ER stress [42], we evaluated the GRP78 protein expression as marker of ER dysfunction.

After $2 \mathrm{~h}$ of EtOH treatment no GRP78 increase was observed, supporting the hypothesis that alcohol is utilized by the cell as a metabolite [43]. On the contrary, an ER stress response was evidenced after $4 \mathrm{~h}$ of treatment. Moreover, the GRP78 expression levels increased as with increasing concentrations of $\mathrm{EtOH}$ in a dose-dependent manner (Figure 5).
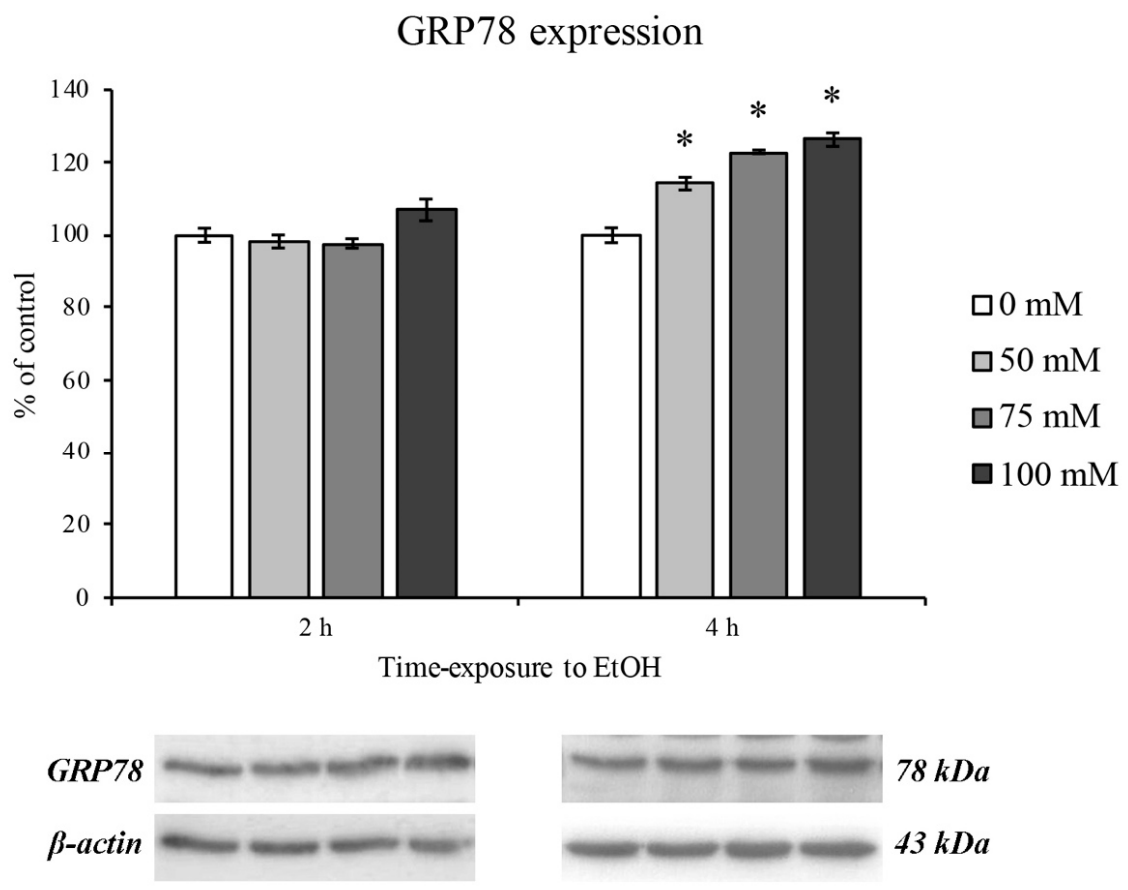

Figure 5. ER stress (GRP78 expression) on RBE4 cells after EtOH treatment. Western blotting analysis 
and quantification of GRP78 expression during EtOH (50, 75 and $100 \mathrm{mM})$ treatments at 2 and $4 \mathrm{~h}$ timepoints. Values are expressed in percentage of control (untreated cells) as the mean \pm S.E.M. of three independent experiments in triplicate. ${ }^{*} p<0.05$ vs. control.

The EtOH-induced ER stress was completely restored after 24 and $48 \mathrm{~h}$ of EtOH withdrawal, as reported in Figure 6.

\section{GRP78 expression after $4 \mathrm{~h}$ EtOH}
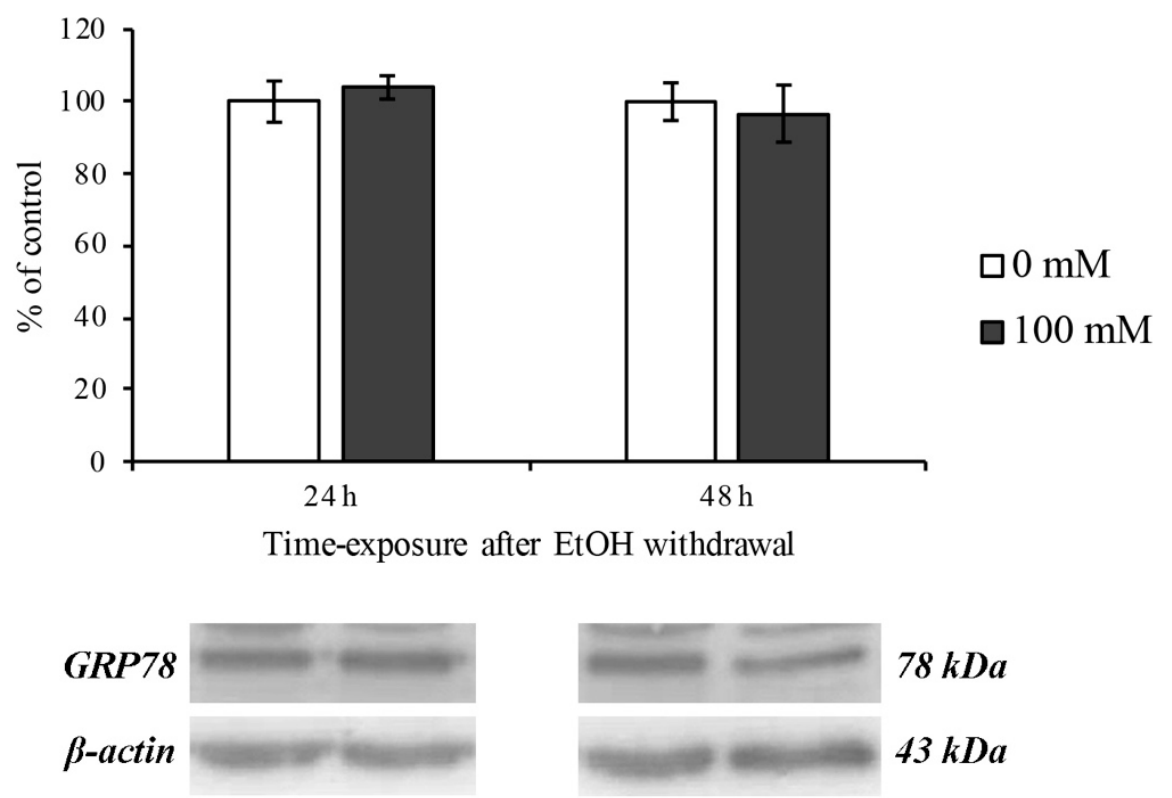

Figure 6. ER stress (GRP78 expression) on RBE4 cells after EtOH withdrawal. Western blotting analysis and quantification of GRP78 expression levels after 24 and 48 of EtOH $100 \mathrm{mM}$ (4 h treatment) withdrawal. Values are expressed in percentage of control (untreated cells) as the mean \pm S.E.M. of three independent experiments in triplicate.

\subsection{Expression of Antioxidant Enzymes}

In order to evaluate the oxidative stress response after EtOH treatment, we evaluated the levels of superoxide dismutase proteins (SOD1 and SOD2) at 2 and $4 \mathrm{~h}$ timepoints (Figure 7, panels A and B, left and right panel, respectively). The results obtained by Western blotting revealed a significant upregulation of SOD1 and SOD2 protein expression and only at the concentration of $75 \mathrm{mM}$ and after $4 \mathrm{~h}$ of $\mathrm{EtOH}$ exposure (Figure 7, panels A and B, dark grey columns).

As previously demonstrated, SOD's activity is abolished at the highest EtOH concentration and time exposure, thus addressing the deleterious effect of prolonged alcohol abuse [44]. 
A
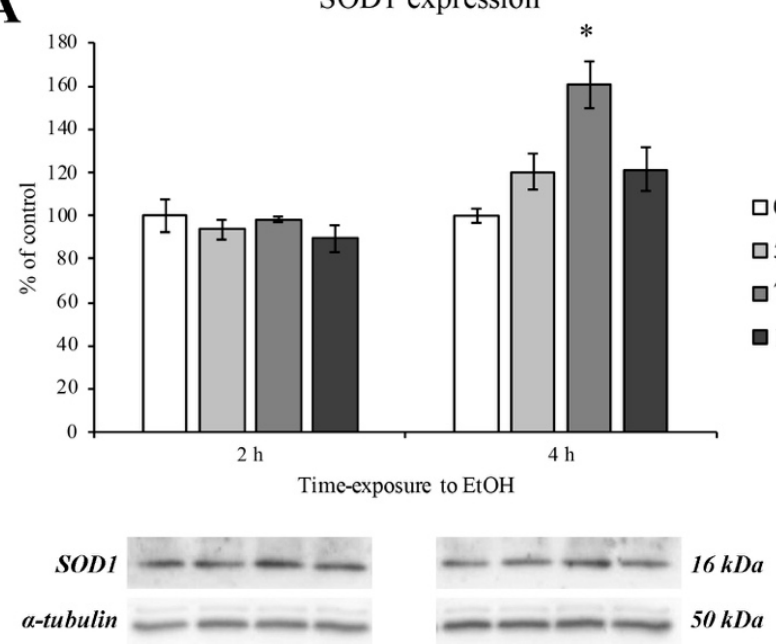

B
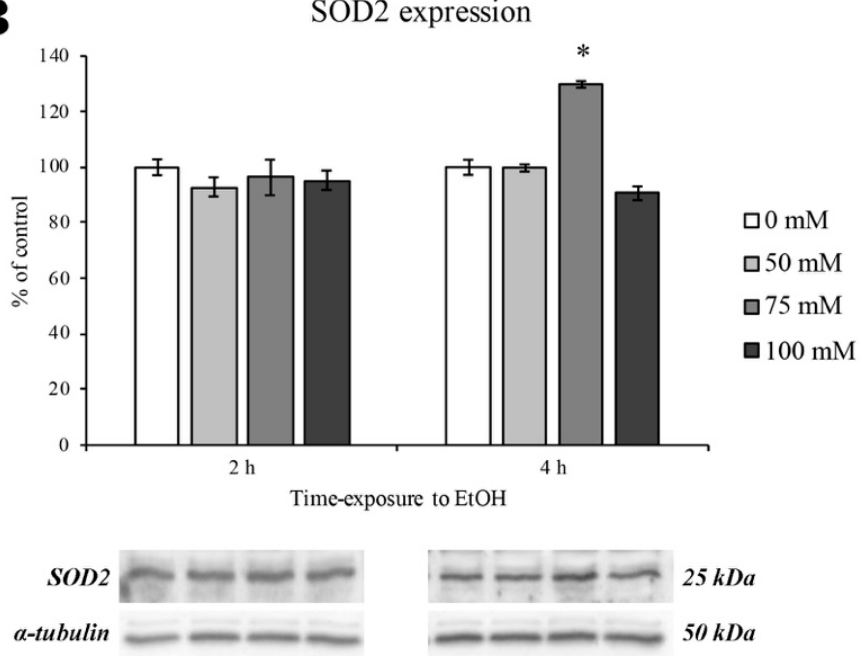

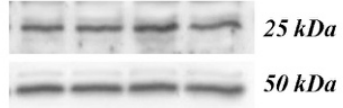

Figure 7. SOD1 and SOD2 expression levels on RBE4 cells after EtOH treatment. Western blotting analysis and quantification of SOD1 (panel A) and SOD2 (panel B) protein expression levels during EtOH (50, 75 and $100 \mathrm{mM}$ ) treatments at 2 and $4 \mathrm{~h}$. Values are expressed in percentage of control (untreated cells) as the mean \pm S.E.M. of three independent experiments in triplicate. ${ }^{*} p<0.05$ vs. control.

\subsection{The Effect of EtOH on the Tight Junction Protein ZO-1}

It has been known that alcohol can reach the brain parenchyma inducing cognitive alteration and impairment depending on its blood stream concentration. Since the brain is protected and enveloped by microvascular endothelial cells that are tightly sealed by tight junction proteins, we performed our last experiments on the evaluation of $\mathrm{ZO}-1$ tight junction protein expression and staining pattern. Actually, ZO-1 protein is needed as an anchor point for the claudin and occludin proteins [45] and is necessary for TJ formation [46]. Because of the specificity of this transmembrane protein to the BBB, it is often used as markers for successful BBB formation.

As shown in Figure 8, ZO-1 expression was significantly decreased only at the highest EtOH concentration $(100 \mathrm{mM})$ and at $4 \mathrm{~h}$ timepoint (panel A, right side).

On the other hand, as clearly shown in Figure 8 (panel B), ZO-1 cellular distribution was severely altered after $1 \mathrm{~h}$ even at lower concentrations ( 50 and $75 \mathrm{mM}$ ) in comparison with control group where a ZO-1 continuous distribution at the cell-cell borders was observed.

This scenario deeply changed after EtOH treatment where a gradual transition from "dot-like" to "zipper-like" structure (arrows) as well as an apparent disruption on the normal junctional integrity (asterisks) was evidenced. Moreover, after $4 \mathrm{~h}$ of $\mathrm{EtOH}$, the ZO-1 staining pattern was almost disappeared and it is no longer possible to distinguish the cell boundaries, confirmed by the ZO-1 protein downregulation by Western blotting analysis.

However, if $\mathrm{EtOH}$ was removed and replaced with $\mathrm{EtOH}$-free medium for the following 24 and $48 \mathrm{~h}$, the ZO-1 restored its normal pattern of distribution, as shown in Figure 9 . 
A

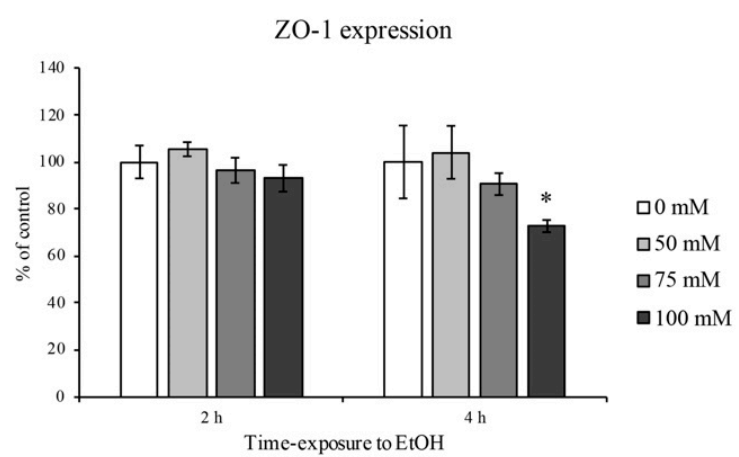

B

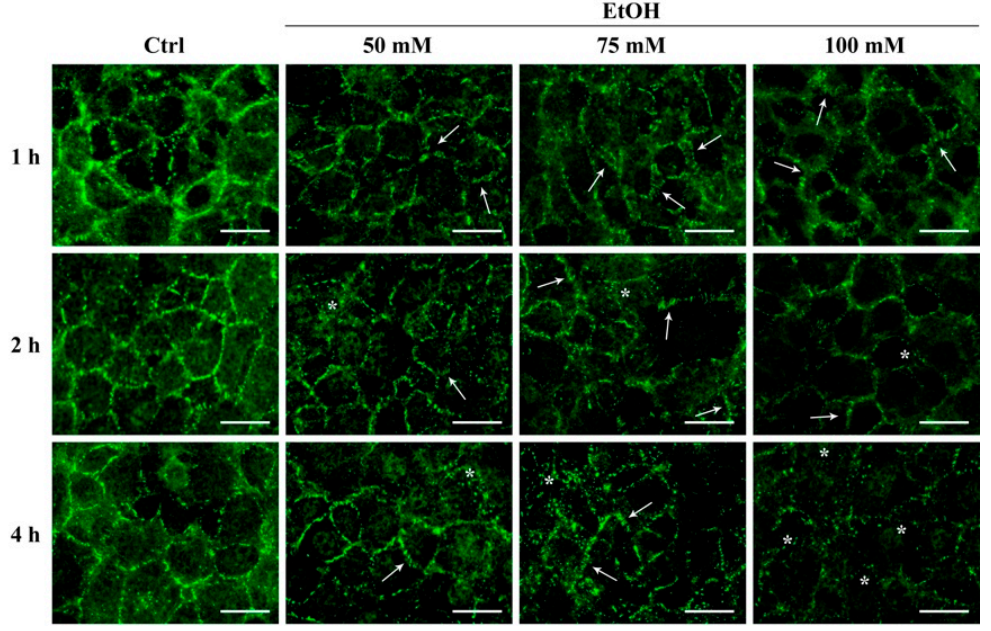

Figure 8. ZO-1 expression and immunofluorescent staining on RBE4 cells after EtOH treatment. (A) Western blotting analysis and quantification of ZO-1 after $\mathrm{EtOH}(50,75$ and $100 \mathrm{mM})$ exposure at 2 and $4 \mathrm{~h}$. Values are expressed in percentage of control (untreated cells) as the mean \pm S.E.M. of three independent experiments in triplicate. ${ }^{*} p<0.05$ vs. control. (B) Changes in ZO-1 distribution were evaluated after EtOH (50, 75 and $100 \mathrm{mM}$ ) treatments at 1, 2, and $4 \mathrm{~h}$ in comparison to control (untreated cells). Arrows show the "zip-like" structure as indicative for morphological alterations in intercellular junctions. Asterisks show the presence of holes formed between endothelial cells. Scale bar: $25 \mu \mathrm{m}$.

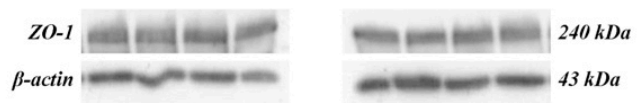

$4 \mathrm{~h}$ EtOH $100 \mathrm{mM}$ withdrawal
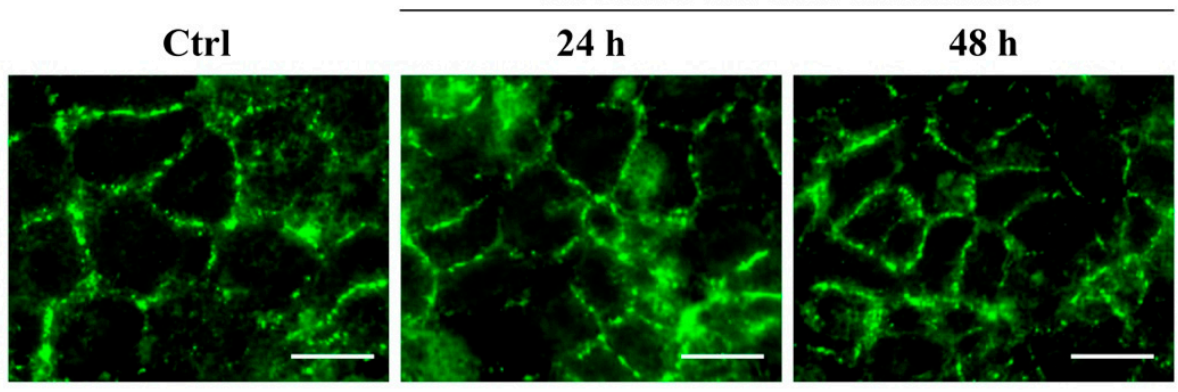

Figure 9. ZO-1 immunofluorescent staining on $\mathrm{RBE} 4$ cells after $\mathrm{EtOH}$ withdrawal. The ZO-1 staining pattern of distribution evaluated after $\mathrm{EtOH}$ withdrawal showing a normal pattern of distribution. Scale bar: $25 \mu \mathrm{m}$.

\section{Discussion}

Among the alcohol-associated disorders, those affecting the nervous system can lead to fatal consequence such as traffic injuries [47], suicide [48,49], and interpersonal violence [50]. Furthermore, recent studies have associated alcohol abuse with many neurodegenerative disorders such as Parkinson's and Alzheimer's diseases, amyotrophic lateral sclerosis, and epilepsy $[11,12,51]$. This latter scenario might be explained as an indirect alcohol abuse association and not as a direct consequence. Indeed, once it has entered the bloodstream, alcohol reaches the systemic organs including the brain.

The brain parenchyma is protected by a tightly sealed and selective wall called BBB. The BBB has the key role to sort out harmless molecules from toxic substances avoiding potential side effects occurring when toxicants enter the nervous system.

In this regard, the role of EtOH-induced permeability of the BBB [51], that in turn induces neurodegenerative disorders and neuroinflammation [19], has been demonstrated by in vivo and post-mortem analysis [52,53]. However, little is known about the signaling pathway triggered by $\mathrm{EtOH}$ that induces permeabilization of the BBB. Aiming to better understand the EtOH-dependent molecular pathway, we treated a rat brain endothelial cell line (RBE4) with EtOH and assessed monolayer tightness by expression and modification of ZO-1 TJ protein pattern of distribution as marker of BBB permeability alteration. 
Firstly, we focused on EtOH concentrations ranging from 10 to $1713 \mathrm{mM}$ in order to evaluate cell viability of RBE4 cells. In accordance with our results, and based on previously reported data on different cell lines [39,54,55], we focused on 50, 75 and $100 \mathrm{mM} \mathrm{EtOH}$ concentration that also mimics the blood alcohol concentrations observed in social drinkers or chronic alcoholics [56], and it may be hypothesized that EtOH effects were reversible after its withdrawal.

According to previously reported data in different BBB in vitro models $[39,54,55,57]$, our results showed that $\mathrm{EtOH}$ rapidly increased $\mathrm{ROS}$ formation $30 \mathrm{~min}$ after treatment at the highest concentrations and levels remained high until $4 \mathrm{~h}$ in comparison to control levels.

It is well known that the most abundant ROS production occurs when mitochondrial electron transport function is compromised, underlining the mitochondria dysfunction $[58,59]$. However, since it has been reported that BAX protein expression induces a pro-oxidant state that is upstream of the ROS overproduction [60], our results are in accordance with these data showing BAX overexpression at $2 \mathrm{~h}$ of EtOH treatment. Interestingly, this scenario completely changed after $4 \mathrm{~h}$ of $\mathrm{EtOH}$ where an increase in the BAX dimeric form is highlighted. This latter form of BAX has been recently found to be enrolled for apoptotic molecular pathway autoinhibition [41]. These data lead us to hypothesize that RBE4 cells try to engage a survival mechanism in order to counteract mitochondria dysfunction and ROS overproduction. However, these adverse effects were completely restored after EtOH withdrawal.

As previously reported [61,62], since mitochondria are closely associated to ER, the activation of BAX can elicit the ER stress signaling cascade. Indeed, the measurement of the ER chaperone GRP78 expression levels, a well-known hallmark and a central regulator of ER stress [63,64], showed a modest, but significant increase only after $4 \mathrm{~h}$ of treatment. Moreover, the GRP78 upregulation was totally reversed by EtOH withdrawal. Considering that the increment in ER stress is likely due to the increase in the toxic metabolites of alcohol such as acetaldehyde and ROS and that the ROS overproduction could be evoked by ER-mitochondria cross talk [65], our results showing an increase in ROS that coincides with that of GRP78 expression would support this hypothesis.

Furthermore, it is worth noticing that at the last timepoint of this study, the RBE4 cells tried again to counteract the oxidative stress, by increasing the level of antioxidant molecules such as SOD1 and SOD2. It has been reported that the SOD family proteins are produced to counteract oxidative stress scavenging ROS [65].

Unfortunately, all these defense mechanisms that endothelial cells put in place to counteract the effect of $\mathrm{EtOH}$ were not sufficient to prevent the TJ protein damage. Even if the ZO-1 expression level decreased only after $4 \mathrm{~h}$ of $100 \mathrm{mM} \mathrm{EtOH}$, alterations of its subcellular distribution occurred at lower timepoints. Indeed, after $1 \mathrm{~h}$ of EtOH exposure, the ZO-1 arrangement, evidenced by immunofluorescence staining, shift from a "dot-" to "zip-like" pattern. The alteration of the ZO-1 distribution pattern is even more marked with increasing EtOH concentrations and exposure times as well as an EtOH-dependent ZO-1 expression downregulation. These alterations were abolished when $\mathrm{EtOH}$ was removed from the culture medium.

These deleterious effects could be linked to EtOH action on different cell compartments. Indeed, as previously reported, oxidative stress, mitochondrial dysfunction and ER stress cause TJ dysregulation that led us to hypothesize the increasing permeability in brain endothelial cells [36].

\section{Conclusions}

The results from this study shed light on the mechanisms underlying alcohol-induced brain endothelial cells dysfunction.

Alcohol metabolism in RBE4 cells produces oxidative and ER stress by ROS production and GRP78 chaperone upregulation, respectively, that may lead to TJ disassembly.

A better understanding of these processes could reveal new potential targets for therapy in brain injuries caused by alcohol abuse and in several EtOH-dependent CNS diseases. 
Author Contributions: Conceptualization, D.C. and A.P.; methodology, D.C., J.J.V.B. and M.B.; validation, J.J.V.B. and A.P.; formal analysis, D.C., J.J.V.B. and M.B.; investigation, D.C., J.J.V.B. and M.B.; resources, M.G., L.D.C.M. and A.P.; data curation, D.C.; writing-original draft preparation, J.J.V.B. and A.P.; writing-review and editing, F.P., G.M. and M.G.; visualization, J.J.V.B.; supervision, A.P.; project administration, A.P. All authors have read and agreed to the published version of the manuscript.

Funding: This research received no external funding.

Institutional Review Board Statement: Not applicable.

Informed Consent Statement: Not applicable.

Conflicts of Interest: The authors declare no conflict of interest.

\section{References}

1. World Health Organization. Management of Substance Abuse Team. In Global Status Report on Alcohol and Health 2018; World Health Organization: Geneva, Switzerland, 2018; ISBN 978-92-4-156563-9.

2. Osna, N.A.; Donohue, T.M., Jr.; Kharbanda, K.K. Alcoholic Liver Disease: Pathogenesis and Current Management. Alcohol Res. Curr. Rev. 2017, 38, 147-161.

3. Larsson, S.C.; Burgess, S.; Mason, A.M.; Michaëlsson, K. Alcohol Consumption and Cardiovascular Disease: A Mendelian Randomization Study. Circ. Genom. Precis. Med. 2020, 13. [CrossRef]

4. Bagnardi, V.; Rota, M.; Botteri, E.; Tramacere, I.; Islami, F.; Fedirko, V.; Scotti, L.; Jenab, M.; Turati, F.; Pasquali, E.; et al. Alcohol Consumption and Site-Specific Cancer Risk: A Comprehensive Dose-Response Meta-Analysis. Br. J. Cancer 2015, 112, 580-593. [CrossRef]

5. Trevejo-Nunez, G.; de Wit, M. Alcohol Use As a Risk Factor in Infections and Healing. Alcohol Res. Curr. Rev. 2015, 37, 177-184.

6. Bishehsari, F.; Desai, V.; Voigt, R.M.; Forsyth, C.B.; Keshavarzian, A. Alcohol and Gut-Derived Inflammation. Alcohol Res. Curr. Rev. 2017, 38, 163-171.

7. Hanck, C.; Whitcomb, D.C. Alcoholic Pancreatitis. Gastroenterol. Clin. N. Am. 2004, 33, 751-765. [CrossRef] [PubMed]

8. Feldman, D.E.; McPherson, K.L.; Biesecker, C.L.; Wiers, C.E.; Manza, P.; Volkow, N.D.; Wang, G.-J. Neuroimaging of Inflammation in Alcohol Use Disorder: A Review. Sci. China Inf. Sci. 2020, 63, 170102. [CrossRef]

9. Li, Q.; Liu, D.; Pan, F.; Ho, C.S.H.; Ho, R.C.M. Ethanol Exposure Induces Microglia Activation and Neuroinflammation through TLR4 Activation and SENP6 Modulation in the Adolescent Rat Hippocampus. Neural Plast. 2019, 2019, 1-12. [CrossRef]

10. Erickson, E.K.; Grantham, E.K.; Warden, A.S.; Harris, R.A. Neuroimmune Signaling in Alcohol Use Disorder. Pharmacol. Biochem. Behav. 2019, 177, 34-60. [CrossRef] [PubMed]

11. Eriksson, A.K.; Löfving, S.; Callaghan, R.C.; Allebeck, P. Alcohol Use Disorders and Risk of Parkinson's Disease: Findings from a Swedish National Cohort Study 1972-2008. BMC Neurol. 2013, 13, 190. [CrossRef] [PubMed]

12. Christoffersen, S. Death from Seizures Induced by Chronic Alcohol Abuse-Does It Exist? Seizure 2007, 16, 379-383. [CrossRef]

13. Crews, F.T.; Collins, M.A.; Dlugos, C.; Littleton, J.; Wilkins, L.; Neafsey, E.J.; Pentney, R.; Snell, L.D.; Tabakoff, B.; Zou, J.; et al. Alcohol-Induced Neurodegeneration: When, Where and Why? Alcohol. Clin. Exp. Res. 2004, 28, 350-364. [CrossRef] [PubMed]

14. Diamond, I.; Messing, R.O. Neurologic Effects of Alcoholism. West. J. Med. 1994, 161, $279-287$.

15. Feigin, V.L.; Nichols, E.; Alam, T.; Bannick, M.S.; Beghi, E.; Blake, N.; Culpepper, W.J.; Dorsey, E.R.; Elbaz, A.; Ellenbogen, R.G.; et al. Global, Regional, and National Burden of Neurological Disorders, 1990-2016: A Systematic Analysis for the Global Burden of Disease Study 2016. Lancet Neurol. 2019, 18, 459-480. [CrossRef]

16. O'Callaghan, J.P.; Sriram, K. Glial Fibrillary Acidic Protein and Related Glial Proteins as Biomarkers of Neurotoxicity. Expert Opin. Drug Saf. 2005, 4, 433-442. [CrossRef]

17. Leyns, C.E.G.; Holtzman, D.M. Glial Contributions to Neurodegeneration in Tauopathies. Mol. Neurodegener. 2017, 12, 50. [CrossRef]

18. Sidoryk-Wegrzynowicz, M.; Strużyńska, L. Dysfunctional Glia: Contributors to Neurodegenerative Disorders. Neural Regen. Res. 2021, 16, 218. [CrossRef]

19. Sweeney, M.D.; Sagare, A.P.; Zlokovic, B.V. Blood-Brain Barrier Breakdown in Alzheimer Disease and Other Neurodegenerative Disorders. Nat. Rev. Neurol. 2018, 14, 133-150. [CrossRef] [PubMed]

20. Carvey, P.M.; Hendey, B.; Monahan, A.J. The Blood-Brain Barrier in Neurodegenerative Disease: A Rhetorical Perspective. J. Neurochem. 2009, 111, 291-314. [CrossRef] [PubMed]

21. Noe, C.R.; Noe-Letschnig, M.; Handschuh, P.; Noe, C.A.; Lanzenberger, R. Dysfunction of the Blood-Brain Barrier-A Key Step in Neurodegeneration and Dementia. Front. Aging Neurosci. 2020, 12, 185. [CrossRef] [PubMed]

22. Daneman, R.; Prat, A. The Blood-Brain Barrier. Cold Spring Harb Perspect. Biol. 2015, 7, a020412. [CrossRef] [PubMed]

23. Daneman, R.; Zhou, L.; Agalliu, D.; Cahoy, J.D.; Kaushal, A.; Barres, B.A. The Mouse Blood-Brain Barrier Transcriptome: A New Resource for Understanding the Development and Function of Brain Endothelial Cells. PLoS ONE 2010, 5, e13741. [CrossRef]

24. Armulik, A.; Genové, G.; Mäe, M.; Nisancioglu, M.H.; Wallgard, E.; Niaudet, C.; He, L.; Norlin, J.; Lindblom, P.; Strittmatter, K.; et al. Pericytes Regulate the Blood-Brain Barrier. Nature 2010, 468, 557-561. [CrossRef] [PubMed] 
25. Alvarez, J.I.; Katayama, T.; Prat, A. Glial Influence on the Blood Brain Barrier: Glial Influence on the Blood Brain Barrier. Glia 2013, 61, 1939-1958. [CrossRef] [PubMed]

26. Greene, C.; Campbell, M. Tight Junction Modulation of the Blood Brain Barrier: CNS Delivery of Small Molecules. Tissue Barriers 2016, 4, e1138017. [CrossRef]

27. Stamatovic, S.; Keep, R.; Andjelkovic, A. Brain Endothelial Cell-Cell Junctions: How to "Open" the Blood Brain Barrier. Curr. Neuropharmacol. 2008, 6, 179-192. [CrossRef]

28. Montagne, A.; Barnes, S.R.; Sweeney, M.D.; Halliday, M.R.; Sagare, A.P.; Zhao, Z.; Toga, A.W.; Jacobs, R.E.; Liu, C.Y.; Amezcua, L.; et al. Blood-Brain Barrier Breakdown in the Aging Human Hippocampus. Neuron 2015, 85, 296-302. [CrossRef]

29. Weiss, N.; Miller, F.; Cazaubon, S.; Couraud, P.-O. The Blood-Brain Barrier in Brain Homeostasis and Neurological Diseases. Biochim. Biophys. Acta (BBA) Biomembr. 2009, 1788, 842-857. [CrossRef]

30. Zlokovic, B.V. The Blood-Brain Barrier in Health and Chronic Neurodegenerative Disorders. Neuron 2008, 57, 178-201. [CrossRef]

31. Manzo-Avalos, S.; Saavedra-Molina, A. Cellular and Mitochondrial Effects of Alcohol Consumption. Int. J. Environ. Res. Public Health 2010, 7, 4281-4304. [CrossRef]

32. Dguzeh, U.; Haddad, N.; Smith, K.; Johnson, J.; Doye, A.; Gwathmey, J.; Haddad, G. Alcoholism: A Multi-Systemic Cellular Insult to Organs. Int. J. Environ. Res. Public Health 2018, 15, 1083. [CrossRef]

33. Lochhead, J.J.; McCaffrey, G.; Quigley, C.E.; Finch, J.; DeMarco, K.M.; Nametz, N.; Davis, T.P. Oxidative Stress Increases BloodBrain Barrier Permeability and Induces Alterations in Occludin during Hypoxia-Reoxygenation. J. Cereb. Blood Flow Metab. 2010, 30, 1625-1636. [CrossRef] [PubMed]

34. Song, K.; Li, Y.; Zhang, H.; An, N.; Wei, Y.; Wang, L.; Tian, C.; Yuan, M.; Sun, Y.; Xing, Y.; et al. Oxidative Stress-Mediated Blood-Brain Barrier (BBB) Disruption in Neurological Diseases. Oxid. Med. Cell. Longev. 2020, 2020, 1-27. [CrossRef]

35. Branca, J.J.V.; Maresca, M.; Morucci, G.; Mello, T.; Becatti, M.; Pazzagli, L.; Colzi, I.; Gonnelli, C.; Carrino, D.; Paternostro, F.; et al. Effects of Cadmium on ZO-1 Tight Junction Integrity of the Blood Brain Barrier. Int. J. Mol. Sci. 2019, 20, 6010. [CrossRef] [PubMed]

36. Branca, J.J.V.; Maresca, M.; Morucci, G.; Becatti, M.; Paternostro, F.; Gulisano, M.; Ghelardini, C.; Salvemini, D.; Di Cesare Mannelli, L.; Pacini, A. Oxaliplatin-Induced Blood Brain Barrier Loosening: A New Point of View on Chemotherapy-Induced Neurotoxicity. Oncotarget 2018, 9, 23426-23438. [CrossRef] [PubMed]

37. Cherpitel, C.J.; Bond, J.; Ye, Y.; Borges, G.; MacDonald, S.; Stockwell, T.; Giesbrecht, N.; Cremonte, M. Alcohol-Related Injury in the ER: A Cross-National Meta-Analysis from the Emergency Room Collaborative Alcohol Analysis Project (ERCAAP). J. Stud. Alcohol. 2003, 64, 641-649. [CrossRef] [PubMed]

38. Deutch, S.R.; Christian, C.; Hoyer, S.; Christensen, E.F.; Dragsholt, C.; Hansen, A.C.; Kristensen, I.B.; Hougaard, K. Drug and Alcohol Use among Patients Admitted to a Danish Trauma Centre: A Prospective Study from a Regional Trauma Centre in Scandinavia. Eur. J. Emerg. Med. 2004, 11, 318-322. [CrossRef] [PubMed]

39. Haorah, J.; Heilman, D.; Knipe, B.; Chrastil, J.; Leibhart, J.; Ghorpade, A.; Miller, D.W.; Persidsky, Y. Ethanol-Induced Activation of Myosin Light Chain Kinase Leads to Dysfunction of Tight Junctions and Blood-Brain Barrier Compromise. Alcohol. Clin. Exp. Res. 2005, 29, 999-1009. [CrossRef]

40. Saeed, R.W.; Varma, S.; Peng, T.; Tracey, K.J.; Sherry, B.; Metz, C.N. Ethanol Blocks Leukocyte Recruitment and Endothelial Cell Activation In Vivo and In Vitro. J. Immunol. 2004, 173, 6376-6383. [CrossRef]

41. Garner, T.P.; Reyna, D.E.; Priyadarshi, A.; Chen, H.-C.; Li, S.; Wu, Y.; Ganesan, Y.T.; Malashkevich, V.N.; Cheng, E.H.; Gavathiotis, E. An Autoinhibited Dimeric Form of BAX Regulates the BAX Activation Pathway. Mol. Cell 2016, 63, 485-497. [CrossRef]

42. Zeeshan, H.; Lee, G.; Kim, H.-R.; Chae, H.-J. Endoplasmic Reticulum Stress and Associated ROS. Int. J. Mol. Sci. 2016, 17, 327. [CrossRef]

43. Wilson, D.F.; Matschinsky, F.M. Ethanol Metabolism: The Good, the Bad, and the Ugly. Med. Hypotheses 2020, $140,109638$. [CrossRef]

44. Haorah, J.; Knipe, B.; Persidsky, Y. Stabilization of Superoxide Dismutase by AcetylLcarnitine in Human Brain Endothelium during Alcohol Exposure: Novel Protective Approach. Free Radic. Biol. Med. 2011, 51, 1601-1609. [CrossRef] [PubMed]

45. Huber, J.D.; Egleton, R.D.; Davis, T.P. Molecular Physiology and Pathophysiology of Tight Junctions in the Blood-Brain Barrier. Trends Neurosci. 2001, 24, 719-725. [CrossRef]

46. Vorbrodt, A.W.; Dobrogowska, D.H. Molecular Anatomy of Intercellular Junctions in Brain Endothelial and Epithelial Barriers: Electron Microscopist's View. Brain Res. Rev. 2003, 42, 221-242. [CrossRef]

47. Papalimperi, A.; Athanaselis, S.; Mina, A.; Papoutsis, I.; Spiliopoulou, C.; Papadodima, S. Incidence of Fatalities of Road Traffic Accidents Associated with Alcohol Consumption and the Use of Psychoactive Drugs: A 7-Year Survey (2011-2017). Exp. Ther. Med. 2019, 18, 2299-2306. [CrossRef]

48. Conner, K.R.; Bagge, C.L.; Goldston, D.B.; Ilgen, M.A. Alcohol and Suicidal Behavior. Am. J. Prev. Med. 2014, 47, S204-S208. [CrossRef]

49. Pompili, M.; Serafini, G.; Innamorati, M.; Dominici, G.; Ferracuti, S.; Kotzalidis, G.D.; Serra, G.; Girardi, P.; Janiri, L.; Tatarelli, R.; et al. Suicidal Behavior and Alcohol Abuse. Int. J. Environ. Res. Public Health 2010, 7, 1392-1431. [CrossRef]

50. Sprunger, J.G.; Eckhardt, C.I.; Parrott, D.J. Anger, Problematic Alcohol Use, and Intimate Partner Violence Victimisation and Perpetration: Anger and Alcohol Use in Intimate Partner Violence. Crim. Behav. Ment. Health 2015, 25, 273-286. [CrossRef] 
51. Peng, B.; Yang, Q.; Joshi, R.B.; Liu, Y.; Akbar, M.; Song, B.-J.; Zhou, S.; Wang, X. Role of Alcohol Drinking in Alzheimer's Disease, Parkinson's Disease, and Amyotrophic Lateral Sclerosis. Int. J. Mol. Sci. 2020, 21, 2316. [CrossRef] [PubMed]

52. Rubio-Araiz, A.; Porcu, F.; Pérez-Hernández, M.; García-Gutiérrez, M.S.; Aracil-Fernández, M.A.; Gutierrez-López, M.D.; Guerri, C.; Manzanares, J.; O'Shea, E.; Colado, M.I. Disruption of Blood-Brain Barrier Integrity in Postmortem Alcoholic Brain: Preclinical Evidence of TLR4 Involvement from a Binge-like Drinking Model: TLR4 Involvement from a Binge-like Drinking Model. Addict. Biol. 2017, 22, 1103-1116. [CrossRef]

53. Pan, W.; Barron, M.; Hsuchou, H.; Tu, H.; Kastin, A.J. Increased Leptin Permeation across the Blood-Brain Barrier after Chronic Alcohol Ingestion. Neuropsychopharmacology 2008, 33, 859-866. [CrossRef] [PubMed]

54. Haorah, J.; Knipe, B.; Leibhart, J.; Ghorpade, A.; Persidsky, Y. Alcohol-induced Oxidative Stress in Brain Endothelial Cells Causes Blood-brain Barrier Dysfunction. J. Leukoc. Biol. 2005, 78, 1223-1232. [CrossRef]

55. Yu, H.; Wang, C.; Wang, X.; Wang, H.; Zhang, C.; You, J.; Wang, P.; Feng, C.; Xu, G.; Zhao, R.; et al. Long-term Exposure to Ethanol Downregulates Tight Junction Proteins through the Protein Kinase C $\alpha$ Signaling Pathway in Human Cerebral Microvascular Endothelial Cells. Exp. Ther. Med. 2017, 14, 4789-4796. [CrossRef] [PubMed]

56. Harrison, N.L.; Skelly, M.J.; Grosserode, E.K.; Lowes, D.C.; Zeric, T.; Phister, S.; Salling, M.C. Effects of Acute Alcohol on Excitability in the CNS. Neuropharmacology 2017, 122, 36-45. [CrossRef]

57. Mureşan, C.; Eremia, I. Ethanol Stimulates the Formation of Free Oxygen Radicals in the Brain of Newborn Rats. Rom. J. Morphol. Embryol. 1997, 43, 113-117.

58. Branca, J.J.V.; Fiorillo, C.; Carrino, D.; Paternostro, F.; Taddei, N.; Gulisano, M.; Pacini, A.; Becatti, M. Cadmium-Induced Oxidative Stress: Focus on the Central Nervous System. Antioxidants 2020, 9, 492. [CrossRef] [PubMed]

59. Pelicano, H.; Lu, W.; Zhou, Y.; Zhang, W.; Chen, Z.; Hu, Y.; Huang, P. Mitochondrial Dysfunction and Reactive Oxygen Species Imbalance Promote Breast Cancer Cell Motility through a CXCL14-Mediated Mechanism. Cancer Res. 2009, 69, $2375-2383$. [CrossRef]

60. Kirkland, R.A.; Windelborn, J.A.; Kasprzak, J.M.; Franklin, J.L. A Bax-Induced Pro-Oxidant State Is Critical for Cytochrome $c$ Release during Programmed Neuronal Death. J. Neurosci. 2002, 22, 6480-6490. [CrossRef]

61. Celardo, I.; Costa, A.C.; Lehmann, S.; Jones, C.; Wood, N.; Mencacci, N.E.; Mallucci, G.R.; Loh, S.H.Y.; Martins, L.M. MitofusinMediated ER Stress Triggers Neurodegeneration in Pink1/Parkin Models of Parkinson's Disease. Cell Death Dis. 2016, 7, e2271. [CrossRef]

62. Li, J.; Zhang, D.; Brundel, B.J.J.M.; Wiersma, M. Imbalance of ER and Mitochondria Interactions: Prelude to Cardiac Ageing and Disease? Cells 2019, 8, 1617. [CrossRef] [PubMed]

63. Lee, A.S. The ER Chaperone and Signaling Regulator GRP78/BiP as a Monitor of Endoplasmic Reticulum Stress. Methods 2005, 35, 373-381. [CrossRef] [PubMed]

64. Oslowski, C.M. (Ed.) Stress Responses; Methods in Molecular Biology; Springer: New York, NY, USA, 2015; Volume 1292; ISBN 978-1-4939-2521-6.

65. Murphy, M.P. Mitochondrial Dysfunction Indirectly Elevates ROS Production by the Endoplasmic Reticulum. Cell Metab. 2013, 18, 145-146. [CrossRef] [PubMed] 